http://dx.doi.org/10.5597/lajam00162

\title{
SOUNDS PRODUCED BY TUCUXI (SOTALIA FLUVIATILIS) from the NAPO AND Aguarico Rivers of Ecuador
}

\author{
Laura J. May-Collado ${ }^{1,2, *}$ and Douglas WartzoK ${ }^{3}$
}

\begin{abstract}
Aвstract: The acoustic structure and repertoire of the tucuxi (Sotalia fluviatilis) remain poorly studied. This lack of information limits our understanding of how acoustic signals evolved and the factors that promote variation across and within populations. Using a broadband recording system, we recorded 30 whistles from tucuxis in the Napo and Aguarico Rivers, Ecuador. Our results show that Ecuadorian tucuxis emit a variety of sounds including whistles, echolocation clicks, and pulse sounds. Whistles structure varied with respect to other populations described in previous studies, providing preliminary evidence of geographic variation. In addition, this study provides evidence of high order harmonics in whistles (up to 80kHz) highlighting the importance of broadband recording systems.

Resumen: La estructura acústica y el repertorio de sonidos del tucuxi (Sotalia fluviatilis) continuan siendo poco estudidos. Esta carencia de información limita nuestro entendimiento de como evolucionan las señales acústicas y de los factores que promueven variaciones inter e intra poblacionales. Usando sistemas de grabación de banda ancha registramos 30 silbidos de tucuxi en los ríos Napo y Aguarico, Ecuador. Nuestros resultados muestran que los tucuxi ecuatorianos emiten una variedad de sonidos incluyendo silbidos, clicks de ecolocalización y pulsos. La estructura de los silbidos varió con respecto a otras poblaciones descritas en estudios anteriores, proporcionando evidencia preliminar de variación geográfica en los sonidos de comunicación de esta especies. Además, este estudio proporciona evidencia de armónicos de alto orden en silbidos (hasta $80 \mathrm{kHz}$ ) destacando la importancia de los sistemas de grabación de amplia banda.
\end{abstract}

KeYwords: Communication, echolocation, pulsed sounds, Delphinidae, tucuxi, Sotalia fluviatilis.

\section{Introduction}

The tucuxi, Sotalia fluviatilis lives in freshwater systems of South America (Flores and da Silva, 2009). Like its marine congener, the Guiana dolphin S. guianensis (Monteiro-Filho et al., 2002; Cunha et al., 2005, Caballero et al., 2007), it is known to produce a variety of sounds, including echolocation clicks, whistles, and burst pulse or graded signals described variously as squawks, screech, bark, whimper, crack, squeal, and squeakysquawks (e.g. Caldwell and Caldwell, 1967; Wiersma, 1982; Kamminga et al., 1983; Wang et al., 1995; 2001). Most of our knowledge on tucuxi sound production (in the wild) comes from studies in the Brazilian Amazon River and tributaries (e.g. Podos et al., 2002; Azevedo and Van Sluys, 2005), Colombia (Diazgranados and Trujillo, 20024; Diazgranados et al., 20025), and one study in Perú (Wang et al., 1995; 2001). Very little is known about their acoustic behavior in other parts of their distribution. Here we report on several types of sounds produced by tucuxi in the Ecuadorian Aguarico and Napo rivers, right on the border with Perú, and compare our results with available information from other populations.

\section{Material and Methods}

This study took place in the Napo and the Aguarico rivers on 17 August 2005. The location of the recorded animals is shown in Figure 1. Acoustic signals were recorded using a broadband system consisting of a RESON hydrophone $(-203 \mathrm{~dB}$ re $1 \mathrm{~V} / \mu \mathrm{Pa}, 1 \mathrm{~Hz}$ to $140 \mathrm{kHz}$ ) connected to an AVISOFT recorder and Ultra Sound Gate 116 (sampling rate $400-500 \mathrm{kHz} 16 \mathrm{bit}$ ), which sent the signals to a laptop computer. Recordings were made continuously, but segmented in $3 \mathrm{~min}$ files. The predominant behavior was noted for every other $3 \mathrm{~min}$ file. When animals were not in sight during a 3 min scanning period, the behavior was noted as unknown.

Five behavioral categories were defined: (1) Feeding/ Foraging, animals actively searching, pursuing, and/ or consuming prey, (2) Social activities, animals interacting among themselves or with the boto, Inia geoffrensis (e.g. body contact, tail slapping) and following the boat or other group members, (3) Traveling, dolphins swimming either slowly or fast while maintaining a defined direction, (4) Resting, animals showing little movement always within the same area

\footnotetext{
${ }^{1}$ Department of Biology, University of Puerto Rico, P.O. Box 23360, San Juan, PR 00931, Puerto Rico.

${ }^{2}$ Department of Environmental Sciences and Policy, George Mason University, 4400 University Drive, David King Hall MSN 5F2, Fairfax, Virginia 22030, USA.

${ }^{3}$ Florida International University, Department of Biological Sciences, 11200 SW $8^{\text {th }}$ Street, Miami Florida 33199, USA

* Corresponding author, e-mail: 1maycollado@gmail.com.

${ }^{4}$ Diazgranados, C. and Trujillo, F. (2002) Vocal repertoire of the freshwater dolphins Inia geoffrensis and Sotalia fluviatilis in Colombia, South America (Abstract 5aAB11). Page 2400 in Proceedings, First Pan-American/Iberian Meeting on Acoustics, December 2002, Cancún, Mexico. Journal of the Acoustical Society of America 112(5)(Pt. 2).

${ }^{5}$ Diazgranados, M.C., Mejía, P. And Acosta, A. (2002) Effect of boat traffic on the vocal and surfacing behavior of river dolphins: A key for abundance estimation methods (Abstract 5pAB3). Page 2431 in Proceedings, First Pan-American/Iberian Meeting on Acoustics, December 2002, Cancún, Mexico. Journal of the Acoustical Society of America 112(5)(Pt. 2).
} 
and diving for short periods of time in relative synchrony with other group members, and (5) Milling, animals moving slowly but changing direction constantly with variable diving periods. In addition, group size and composition, photo-identification photographs, and GPS data were also collected.

Seven sightings of tucuxi were made and recordings were obtained from all. Six sightings consisted of solitary animals and one of a mixed group of five tucuxis and two botos. A total of 53 files (each $3 \mathrm{~min}$ long) were obtained accounting for approximately $2.65 \mathrm{~h}$ of recorded time. Sounds were broadly categorized as: whistles, click trains, and burst sounds. Whistles were defined as narrowband and frequency modulated sounds (Richardson et al., 1995). Click trains and burst sounds were differentiated based on mean interclick interval (ICI), clicks having a mean ICI longer than $10 \mathrm{~ms}$ and burst pulses less than $10 \mathrm{~ms}$ (see Lammers et al., 2004).

Both whistles and pulsed sounds were manually analyzed using the program Raven 1.1 (Cornell Laboratory of Ornithology, New York) and Cool Edit 96 with a Hann sample window of 522, FFT (Fast Fournier Transformation) size of 1024 points, and overlap of $50 \%$. The following standard acoustic parameters were measured for whistle fundamental (not considering harmonics): starting frequency (SF), ending frequency (EF), minimum frequency (MinF), maximum frequency $(\operatorname{MaxF})$, delta frequency $(\mathrm{DF}=\mathrm{MaxF}-\mathrm{MinF})$, and duration (ms). For clicks and burst trains the following parameters were measured \#clicks/train, click repetition rate (\#clicks/s), interclick interval (ms), duration (s), and dominant frequency $(\mathrm{kHz})$ for selected individual clicks within each click train.
Because the waveform of each individual click within a click train tends to be repetitive and stereotyped ( $\mathrm{Au}$ et al., 1974) we selected two clicks from six click trains to measure dominant frequency. The relative background energy at each frequency was subtracted from the analyzed clicks.

In addition, using available published information about the mean and standard deviation for each whistle parameter (Table 1) we did pairwise comparisons between tucuxi populations. We first tested the null hypothesis that the variances are equal using the F-test and then the t-test to test the null hypothesis of equal means at the level of significance of 0.05 (Ambrose and Ambrose, 1995).

\section{Results}

WHISTLES

A total of 30 good quality whistles were recorded from two of the seven sightings (Table 1). Nine of the whistles were recorded from a solitary tucuxi engaged in milling behavior at the intersection of the Napo and Aguarico rivers. The other 21 whistles were recorded from the mixed-species group when the animals were foraging.

About $63 \%$ of these whistles contained harmonics (one to seven harmonics), but in only $48 \%$ of the whistles harmonics were clear enough for measurements. Harmonics minimum frequency ranged from 10.89 to $50.95 \mathrm{kHz}$, maximum frequency from 23.06 to $83.5 \mathrm{kHz}$, and frequency with peak energy from 11.23 to $83.5 \mathrm{kHz}$ (Figure 2a).

Pairwise comparisons suggest tucuxi populations vary

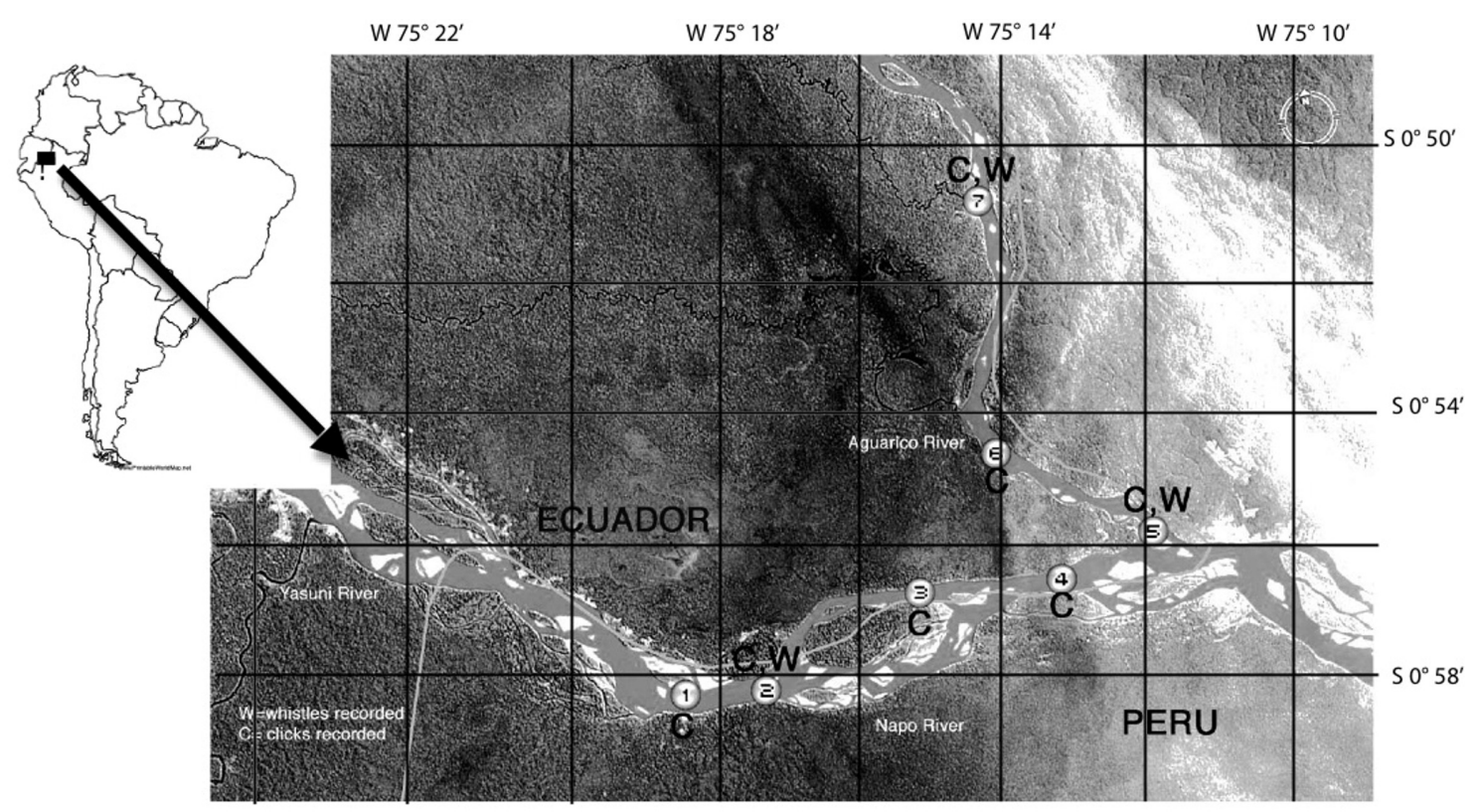

Figure 1. Geographical position of each tucuxi sighting and type of sounds recorded in each sighting $(\mathrm{C}=$ clicks $/$ bursts, $\mathrm{W}=$ whistles $)$. 
in whistle parameters (Table 2). Tucuxis from the Mamirauá Reserve whistle significantly lower in frequency than those from the Marañon-Tigre rivers and the Pacaja River. Maximum whistle frequency was significantly higher in tucuxis from Pacaja River than those from other populations (all comparisons were significant except for the Marañon-Tigre rivers and Mamirauá Reserve). Start frequency is significantly higher in Aguarico - Napo Rivers compared to
Mamirauá Reserve, but no significant differences were found for any other comparisons. Ending frequency was significantly higher in tucuxis from the Pacaja River compared to the other populations. Whistles were longer in tucuxis from Mamirauá Reserve compared to those from the Pacaja and Aguarico-Napo rivers. Finally, whistles were more frequency modulated in tucuxis from the Marañon-Tigre rivers compared to those of the Aguarico-Napo Rivers and Pacaja River.

Table 1. Frequency and time parameters measured on Sotalia fluviatilis whistle fundamentals from the Napo and Aguarico Rivers, Ecuador in comparison with other studies.

\begin{tabular}{|c|c|c|c|c|c|c|c|c|}
\hline & $\begin{array}{l}\text { MinF } \\
(\mathrm{kHz})\end{array}$ & $\begin{array}{l}\text { MaxF } \\
(\mathrm{kHz}) \\
\end{array}$ & $\begin{array}{l}\text { DeltaF } \\
(\mathrm{kHz}) \\
\end{array}$ & $\begin{array}{c}\mathrm{SF} \\
(\mathrm{kHz}) \\
\end{array}$ & $\begin{array}{c}\mathrm{EF} \\
(\mathrm{kHz}) \\
\end{array}$ & $\begin{array}{c}\text { Duration } \\
\text { (s) } \\
\end{array}$ & $\begin{array}{c}\text { \#Inflection } \\
\text { Points } \\
\end{array}$ & Source \\
\hline Mean & 10.61 & 17.69 & 7.22 & 12.82 & 13.57 & 0.374 & 0.731 & $\mathrm{n}=30$ \\
\hline$S D$ & 3.19 & 4.64 & 3.56 & 5.50 & 3.36 & 0.249 & 0.874 & Aguarico/Napo Rivers \\
\hline Range & $5.17-15.04$ & $7.79-28.84$ & $1.76-19.42$ & $5.17-28.83$ & $6.84-20.51$ & $0.007-0.785$ & $0-2$ & Ecuador (this study) \\
\hline$C V \%$ & 30.0 & 26.2 & 49.3 & 42.9 & 24.7 & 66.6 & 119.7 & \\
\hline Mean & 10.93 & 19.95 & 9.02 & 11.36 & 19.63 & 0.381 & 0.44 & $\mathrm{n}=61$ \\
\hline$S D$ & 3.39 & 2.43 & 3.59 & 3.81 & 2.41 & 0.172 & 0.74 & Pacaja River, Northern \\
\hline Range & $5.19-18.88$ & $12.3-23.87$ & $1.9-15.2$ & $5.19-20.62$ & $12.3-23.07$ & $0.067-0.814$ & $0-3$ & Brazil \\
\hline$C V \%$ & 31 & 12.2 & 39.8 & 33.5 & 20.7 & 45.2 & 168.2 & $\begin{array}{c}\text { (Azevedo and Van Sluys, } \\
\text { 2005) }\end{array}$ \\
\hline Mean & 9.18 & 15.65 & ------- & 9.70 & 14.64 & 0.630 & ------- & $\mathrm{n}=50$ \\
\hline$S D$ & 3.05 & 2.49 & ------- & 3.64 & 2.66 & 0.320 & ------- & Mamirauá Reserve, \\
\hline Range & ------ & ------ & ------ & ------ & ------ & ------ & ------ & Amazonian \\
\hline$C V \%$ & 33.2 & 15.9 & ------ & 37.6 & 18.2 & 50.8 & ------ & $\begin{array}{c}\text { Brazil } \\
\text { (Podos et al., 2002) }\end{array}$ \\
\hline Mean & 10.210 & 15.410 & ------- & 10.760 & 14.350 & 0.410 & 1.38 & $n=155$ \\
\hline$S D$ & 3.10 & 3.11 & ------ & 3.53 & 2.89 & 0.210 & 2.19 & Marañon and Tigre \\
\hline Range & $3.65-18.14$ & $8.28-23.86$ & ------- & $3.64-21.21$ & $7.89-23.11$ & $0.06-1.04$ & $0-16$ & Rivers, Amazonian, Peru \\
\hline$C V \%$ & 30.39 & 20.18 & ------- & 32.77 & 20.15 & 51.10 & 158.4 & (Wang et al., 1995; 2001) \\
\hline
\end{tabular}

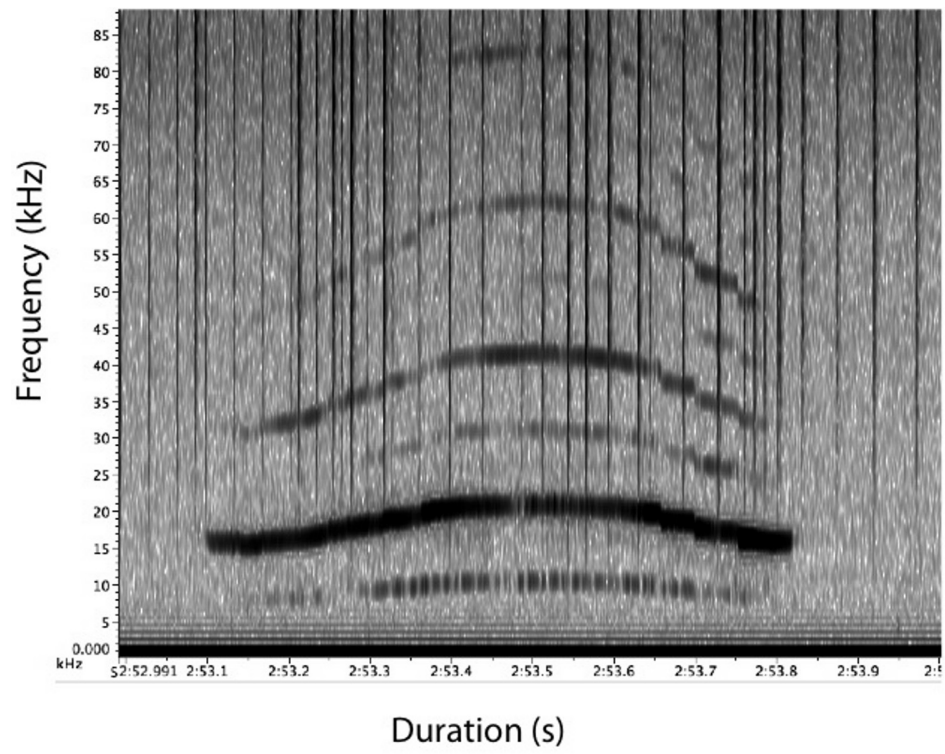

a.

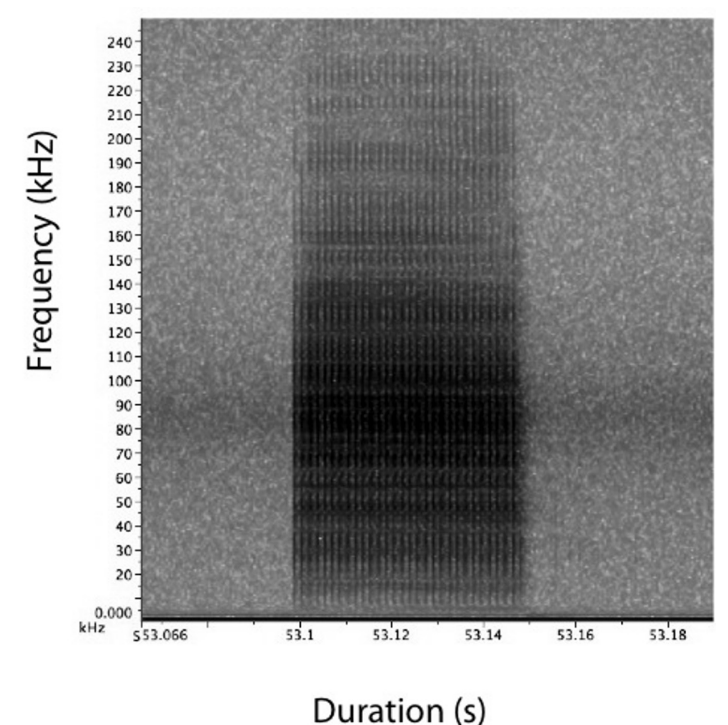

b.

Figure 2. Examples of whistle contour (a) and burst sound (b) recorded from tucuxi in this study. 
Table 2. Significant pairwise comparisons of Sotalia fluviatilis whistle parameters.

\begin{tabular}{|c|c|c|c|c|c|c|c|}
\hline Statistic & $\begin{array}{l}\mathrm{MinF} \\
(\mathrm{kHz}) \\
\end{array}$ & $\begin{array}{l}\operatorname{MaxF} \\
(\mathrm{kHz}) \\
\end{array}$ & $\begin{array}{c}\mathrm{SF} \\
(\mathrm{kHz})\end{array}$ & $\begin{array}{l}\text { EndF } \\
(\mathrm{kHz})\end{array}$ & $\begin{array}{c}\text { Duration } \\
\text { (s) }\end{array}$ & $\begin{array}{c}\text { \#Inflection } \\
\text { Points } \\
\end{array}$ & Population \\
\hline $\begin{array}{c}t \text {-student } \\
d f\end{array}$ & n.s. & $\begin{array}{c}6.94 \\
100.8\end{array}$ & n.s. & $\begin{array}{c}13.6 \\
135.7\end{array}$ & n.s. & $\begin{array}{l}4.7 \\
213\end{array}$ & $\begin{array}{c}\text { Marañon and Tigre Rivers } \\
\text { vs. } \\
\text { Pacaja River }\end{array}$ \\
\hline $\begin{array}{c}t \text {-student } \\
\quad d f\end{array}$ & $\begin{array}{l}2.1 \\
203\end{array}$ & n.s. & n.s. & n.s. & n.s. & ----- & $\begin{array}{c}\text { Marañon and Tigre Rivers } \\
\text { vs. } \\
\text { Mamirauá Reserve, } \\
\text { Amazonian }\end{array}$ \\
\hline $\begin{array}{c}t \text {-student } \\
\quad d f\end{array}$ & n.s. & $\begin{array}{l}2.45 \\
31.9\end{array}$ & n.s. & n.s. & n.s. & $\begin{array}{l}2.71 \\
94.7\end{array}$ & $\begin{array}{c}\text { Marañon and Tigre Rivers } \\
\text { vs. } \\
\text { Aguarico and Napo } \\
\text { Rivers }\end{array}$ \\
\hline $\begin{array}{c}t \text {-student } \\
d f\end{array}$ & $\begin{array}{l}2.86 \\
112\end{array}$ & $\begin{array}{l}9.35 \\
107\end{array}$ & n.s. & $\begin{array}{c}10.2 \\
103.6\end{array}$ & $\begin{array}{c}5 \\
75.6\end{array}$ & ----- & $\begin{array}{l}\text { Pacaja River vs. } \\
\text { Mamirauá Reserve, } \\
\text { Amazonian }\end{array}$ \\
\hline $\begin{array}{c}t \text {-student } \\
\quad d f\end{array}$ & n.s. & $\begin{array}{l}2.37 \\
32.2\end{array}$ & n.s. & $\begin{array}{c}5.5 \\
31.4\end{array}$ & n.s. & n.s. & $\begin{array}{c}\text { Pacaja River vs. } \\
\text { Aguarico and Napo } \\
\text { Rivers }\end{array}$ \\
\hline $\begin{array}{c}t \text {-student } \\
\quad d f\end{array}$ & n.s. & $\begin{array}{l}2.15 \\
33.4\end{array}$ & $\begin{array}{l}2.58 \\
37.4\end{array}$ & n.s. & $\begin{array}{c}4 \\
69.9\end{array}$ & ----- & $\begin{array}{l}\text { Mamirauá Reserve, } \\
\text { Amazonian vs. } \\
\text { Aguarico and Napo } \\
\text { Rivers }\end{array}$ \\
\hline
\end{tabular}

n.s. $=$ not significant results at the 0.05 level of significance.

\section{Click tRains}

A total of 22 click trains from four solitary tucuxis were selected for measurements based on their signal/noise quality. Clicks were emitted by one animal when milling and by the other three during foraging. No clicks were analyzed from the mixed-species group because of overlap between click trains. We also did not include click trains from the other two solitary tucuxis due to high background noise. Click trains contained from seven to 99 clicks (mean $=36.86, \mathrm{SD}=$ 27.92) with a mean duration of $2.58 \pm 1.89$ s (range 0.497 to 7.539$)$. Click repetition rate was $15.35 \pm 6.38$ clicks per second and mean ICI was $67.8(\mathrm{SD}=25.2)$. Click dominant frequency was $88.35 \mathrm{kHz}(\mathrm{SD}=3.01)$ and mean duration $109.2 \mathrm{~ms}(\mathrm{SD}=31.97)$.

\section{BURST SOUNDS}

Only one short burst sound (50ms) was produced by a solitary tucuxi; it consisted of 30 clicks with a mean interclick interval of $2 \mathrm{~ms}$. A total of 26 bursts sounds (with good signal noise ratio) were analyzed from the mixed-species group (Figure 2b). Animals were engaged in foraging activities within a small area continuously during the recording period. We do not know if both or only one species emitted these sounds. However, our recordings of boto dolphins from the Yasuní River did not contain burst sounds. Of all burst trains only one had an ICI of $1 \mathrm{~ms}$, for all others the ICI was $2 \mathrm{~ms}$. Overall, burst trains contained $26.9(\mathrm{SD}=13.7)$ clicks per train with mean duration of $46 \mathrm{~ms}(\mathrm{SD}=22.8)$. Mean dominant frequency was 77.62 $\mathrm{kHz}(\mathrm{SD}=11.85)$.

\section{Discussion}

Ecuadorian tucuxis emitted a variety of sounds including whistles, pulsed and echolocation clicks. The acoustic structure of these sounds is similar to that described in previous studies (e.g. Caldwell and Caldwell, 1967; Wiersma, 1982; Wang et. al., 1995; 2001). However, whistle structure comparisons between this study and others, suggest these sound may vary geographically as reported in its sister species the marine S. guianensis (e.g. May-Collado and Wartozk, 2009; RossiSantos and Podos, 2006; Azevedo and Van Sluys, 2005). This is interesting, as one would expect freshwater environments to be relatively homogenous in their acoustic properties. However, differences in 'microhabitat' (e.g. rapids, lakes, etc.) may influence whistle structure as well as the degree of contact (or isolation) between these populations as it has been shown in $S$. guianensis, where adjacent populations are more similar in their whistle parameters (particularly frequency) (Azevedo and Van Sluys, 2005; Rossi-Santos and Podos, 2006; May-Collado and Wartok, 2009). In addition, S. guianensis shows an overall pattern of increasing in frequency from southern to northern populations (Azevedo and Van Sluys, 2005; Rossi-Santos and Podos, 2006; May-Collado and Wartzok, 2009).

The whistles recorded from the mixed species group were more likely emitted by tucuxis and not by botos. May-Collado and Wartzok (2007) contrasted the differences between these whistles and those of botos from the Yasuní River, located about $14 \mathrm{~km}$ upstream from this study area, and found significant differences in the contour and acoustic parameters of the two species. 
In addition, these 21 whistles had similar contours to those described for other tucuxi populations and the sister species S. guianensis (e.g. Monteiro-Filho and Monteiro, 2001; Podos et al., 2002; Azevedo and Van Sluys, 2005; Azevedo and Simão, 2002; May-Collado and Wartzok, 2009) (Figure 2a).

This is the first time that whistles with high frequency harmonics have been reported in S. fluviatilis. These high frequency whistle harmonics may not be exclusive to this Ecuadorian population but may have been undetected in other studies due to the limitations in the maximum frequency of the recording equipment. Until now all S. fluviatilis acoustic studies have used recording systems limited to $25 \mathrm{kHz}$. The fundamental frequency did not exceed this $25 \mathrm{kHz}$ limit, but until we have full frequency range recordings from other S. fluviatilis populations, the production and role of high frequency whistle harmonics will remain unknown. The presence of high order harmonics in whistles has been recently described for its sister species S. guianensis (May-Collado and Wartzok, 2009). In the distantly Stenella longirostris and Orcinus orca high-frequency harmonic whistles are associated with direction and coordination as the animals travel from one area to another (Miller, 2002; Lammers and $\mathrm{Au}, 2003)$.

Click repetition rate, duration, and dominant frequency values were similar to those described in previous studies (e.g. Norris et al. 1992; Kamminga et al. 1993). However, further comparisons are limited due to differences in data analysis approaches and recording systems. Finally, this study provides the first descriptions of tucuxi burst pulses. Similarly to burst pulses of spinner and spotted dolphins (Lammers et al. 2003), tucuxis emit burst pulses that are predominantly ultrasonic. However, there is contrast in the context in which they are produced: while in spinner and spotted dolphins burst pulses have been recorded during social events, in this study tucuxis emitted burst pulses when solitary and in the presence of botos during foraging events. However, this may be due to a small sample size.

This study provides insights on the sound repertoire of tucuxis in Ecuador and provides new information on the emission of high order harmonics, and geographical variation. Future studies should use recording systems with a broader bandwidth of at least $150 \mathrm{kHz}$ to ensure the inclusion of high order harmonics and burst pulses and thus gain more information about their role in dolphin communication.

\section{Acknowledgements}

We thank Marco Rossi-Santos (Brazilian Dolphin Sotalia guianensis Vocalizations Project), Ingi Agnarsson (University of Puerto Rico), the Editor Daniel Palacios and two anonymous reviewers for helpful comments and suggestions to this manuscript. Thanks to Alonso Jaramillo (Parque Nacional Yasuní, Ecuador), Luis
Albuja (Departamento de Ciencias Biológicas, Escuela Politécnica Nacional), field assistants Mónica GamboaPoveda and Angélica Caiza, the boat captains Walter Prado and Daniel Contreras, biologists Víctor Utreras and Judith Denkinger, the locals Don Segundo, Estuardo Hidalgo, and all the park rangers at Yasuní National Park. Recordings were carried out with permission of the Ministerio del Ambiente de la República del Ecuador (Permit No. 019-IC-FL-PNY-RSO) and authorization from the Institutional Animal Care and Use Committee at Florida International University. Judith Parker Travel Grant, Cetacean International Society, Project Aware, and Russell E. Train Education Program-WWF provided funding to Laura May-Collado.

\section{References}

Ambrose, H.W. and Ambrose, K.P. (1995) A Handbook of Biological Investigation. Editorial Hunter Texbooks Inc., North Carolina, USA.

Au, W.W.L., Floyd, R.W., Penner, R.H. and Murchison, A.E. (1974) Measurements of echolocation signals of the Atlantic bottlenose dolphin, Tursiops truncatus (Montagu), in open waters. Journal of the Acoustical Society of America 56(4): 12801290. http:// dx.doi.org/10.1121/1.1903419

Azevedo, A.F. AND Simão, S.M. (2002) Whistles produced by marine tucuxi dolphins (Sotalia fluviatilis) in Guanabara Bay, southeastern Brazil. Aquatic Mammals 28(3): 261-266.

Azevedo, A.F. ANd Van Sluys, M. (2005) Whistles of tucuxi dolphins (Sotalia fluviatilis) in Brazil: comparisons among populations. Journal of the Acoustic Society of America 117(3): 1456-1464. http://dx.doi.org/10.1121/1.1859232

Caballero, S., Trujillo, F., Vianna, J.A., Barrios-Garrido, H., Montiel, M.G., Beltrán-Pedreros, S., Marmontel, M., Santos, M.C.O., Rossi-SAntos, M., SANTOS, F.R. AND BAKER, C.S. (2007) Taxonomic status of the genus Sotalia: species level ranking for 'tucuxi' (Sotalia fluviatilis) and 'costero' dolphins (Sotalia guianensis). Marine Mammal Science 23(2): 358-386. http://dx.doi.org/10.1111/j.1748-7692.2007.00110.x

Caldwell, M.C. and Caldwell, D.K. (1967) Intra-specific transfer of information via the pulsed sound in captive odontocete cetaceans. Pages 879-936 in Busnell, R.G. (Ed) Animal Sonar Systems. Plenum Press, New York, USA.

Cunha, H.A., Da Silva, V.M.F, Lailson-Brito, JR, J., Santos, M.C.O., Flores, P.A.C., Martin, A.R., Azevedo, A.F., Fragoso, A.B.L., Zanelatto, R.C. and Solé-Cava, A.M. (2005) Riverine and marine ecotypes of Sotalia dolphins are different species. Marine Biology 148(2): 449-457. http://dx.doi.org/10.1007/ s00227-005-0078-2

Flores, P.A.C. AND DA SILVA V.M.F. (2009) Tucuxi and Guiana dolphin - Sotalia fluviatilis and S. guianensis. Pages 1188-1191 in Perrin, W.F., Würsig, B. and Thewissen, J.G.M. (Eds) Encyclopedia of Marine Mammals. 2nd ed. Academic Press, Amsterdam, Netherlands.

Kamminga, C., van Hove, M.T., Engelsma, F.J. and Terry, R.P. 1993. Investigations on Cetacean Sonar X: A comparative analysis of underwater echolocation of Inia spp. and Sotalia spp. Aquatic Mammals 19(1):31-43. http:/ / dx.doi.org/10.1578/ AM.36.4.2010.331 
Lammers, M.O. AND Au, W.W.L. (2003) Directionality in the whistles of Hawaiian spinner dolphins (Stenella longirostris): a signal feature to cue direction of movement? Marine Mammal Science 19(2): 249-264. http://dx.doi.org/10.1111/j.17487692.2003.tb01107.x

Lammers, M.O., Au, W.W.L. and Herzing, D.L. (2003). The broadband social acoustic signaling behavior of spinner and spotted dolphins. Journal of the Acoustical Society of America 114(3): 1629-1639. http://dx.doi.org/10.1121/1.1596173

Lammers, M.O., Au, W.W.L., Aubauer, R. and Nachtigall, P.E. (2004) A comparative analysis of the pulsed emissions of freeranging Hawaiian spinner dolphins (Stenella longirostris). Pages 414-419 in Thomas, J.A., Moss, C. F. And Vater, M. (Eds) Echolocation in Bats and Dolphins. The University of Chicago Press, Chicago, USA.

May-Collado, L.J. And WARTZOK, D. (2007) The freshwater dolphin Inia geoffrensis geoffrensis produces high frequency whistles. Journal of the Acoustic Society of America 121(2): 12031212. http://dx.doi.org/10.1121/1.2404918

May-Collado, L.J. and WartzoK, D. (2009) A characterization of Guiana dolphin (Sotalia guianensis) whistles from Costa Rica: The importance of broadband recording systems. Journal of the Acoustical Society of America 125(2): 1202-1213. http:// dx.doi.org/10.1121/1.3058631

Miller, P.J.O. (2002) Mixed-directionality of killer whale stereotyped calls: a direction of movement cue? Behavioral Ecology and Sociobiology 52(3): 262-270. http://dx.doi.org/ 10.1007 / s00265-002-0508-9

Monteiro-Filho, E.L.A., Monteiro, L.R. AND Dos Reis, S.F. (2002) Skull shape and size divergence in dolphins of the genus Sotalia: a tridimensional morphometric analysis. Journal of Mammalogy 83(1): 125-134. http://dx.doi.org/10.1644/15451542(2002)083\%3C0125:SSASDI\%3E2.0.CO;2

Monteiro-Filho, E.L.A. AND Monteiro, K.D.K.A. (2001) Lowfrequency sounds emitted by Sotalia fluviatilis guianensis (Cetacea:Delphinidae) in an estuarine region in Southeastern Brazil. Canadian Journal of Zoology 79(1): 59-66. http:/ / dx.doi.org/ 10.1139/z00-166

Murray, S.O., Mercado, E. and Roitblat, H.L. (1998) Characterizing the graded structure of false killer whale (Pseudorca crassidens) vocalizations. Journal of the Acoustical Society of America 104(3): 1679-1688. http://dx.doi.org/ $10.1121 / 1.424380$

Norris, K.S., Harvey, G.W., Burzell, L.A., AND Krishna Kartha, T.D. (1992). Sound production in the freshwater porpoises Sotalia cf fluviatilis GERVAIS and DEVILLE and Inia geoffrensis Blainville, in the Rio Negro, Brazil. Pages 251-262 in PILLERI, G. (Ed) Investigations on cetacea. Volume IV. Hirnanatomisches Institut der Universität, Germany, Berne.

Podos, J., da Silva, V.M.F. and Rossi-Santos, M.R. (2002) Vocalizations of Amazon river dolphins, Inia geoffrensis: insights into the evolutionary origins of delphinid whistles. Ethology 108: 601-612. http://dx.doi.org/10.1046/j.14390310.2002.00800.x

Richardson, W.J., Greene, C.R., Malme, C.I. and Thomson, D.H. (1995) Marine Mammals and Noise. Academic Press, San Diego, USA.

Rossi-SANTOS, M.R., AND Podos, J. (2006) Latitudinal variation in whistle structure of the estuarine dolphin Sotalia guianensis. Behaviour 143(7): 347-364. http://dx.doi.org/10.1163/ 156853906775897905

Wang, D., Wursig, B. AND Evans, W.E. (1995) Whistles of bottlenose dolphins: comparisons among populations. Aquatic Mammals 21(1): 65-77.

WANG, D., WuRSIG, B. AND LEATHERWOOD, S. (2001). Whistles of boto, Inia geoffrensis, and tucuxi, Sotalia fluviatilis. Journal of the Acoustic Society of America 109(1): 407-414. http:/ / dx.doi.org/ $10.1121 / 1.1326082$

Wiersma, H. (1982). A comparison of wave shapes of odontocete sonar signals. Aquatic Mammals 9(2): 57-66. 